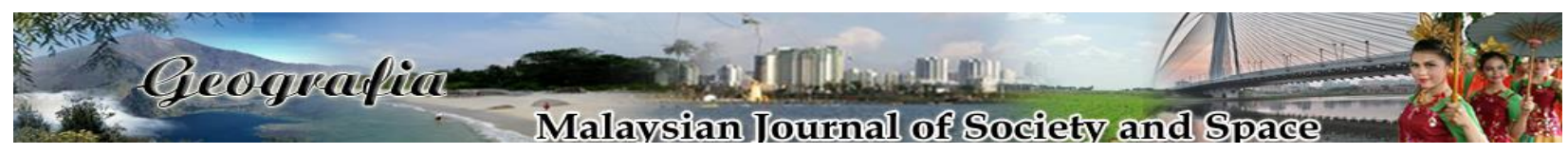

\title{
Pengetahuan gelandangan terhadap peranan dan keperluan pekerja sosial
}

\author{
Syazwani Drani, Azlinda Azman, Paramjit Singh Jamir Singh \\ Program Kerja Sosial, Pusat Pengajian Sains Kemasyarakatan, Universiti Sains Malaysia \\ Correspondence: Syazwani Drani (email: syazwanid@usm.my)
}

Received: 9 November 2018; Accepted: 4 April 2019; Published: 14 May 2019

\begin{abstract}
Abstrak
Bergelandangan menuntut individu yang terlibat menjalani kehidupan tanpa perlindungan kediaman dan kerjaya yang stabil. Di Malaysia, negeri yang direkodkan oleh Jabatan Kebajikan Masyarakat Malaysia (JKMM) mempunyai masalah gelandangan adalah Kuala Lumpur, Selangor, Johor Pulau Pinang, dan Sarawak. Masalah yang dialami oleh individu yang bergelandangan terdiri daripada kemiskinan, masalah mental dan fizikal, penyalahgunaan alkohol dan bahan-bahan lain, pengangguran dan kadar upah yang rendah. Kajian kualitatif yang dijalankan bertujuan mengenal pasti status pengetahuan gelandangan terhadap kewujudan agensi yang memberi khidmat bantuan berbentuk intervensi dan perkhidmatan kaunseling yang disediakan oleh pekerja sosial kepada golongan gelandangan khususnya di George Town, Pulau Pinang. Temu bual secara mendalam telah dilakukan ke atas 20 orang informan yang terlibat secara sukarela. Data yang diperolehi dianalisis menggunakan kaedah analisis kandungan. Hasil kajian menunjukkan bahawa golongan gelandangan mengetahui kewujudan agensi swasta dan kerajaan yang menawarkan khidmat bantuan kepada mereka. Namun, kajian mendapati informan yang ditemu bual memilih untuk tidak mendapatkan khidmat daripada agensi terbabit. Alasan mereka menjurus kepada tiada keperluan untuk berjumpa pekerja sosial, tiada kepastian pekerja sosial untuk membantu, tidak mengetahui cara dan kaedah untuk berjumpa serta belum bersedia untuk berkongsi masalah. Sehubungan itu, kajian yang dijalankan mencadangkan agar pekerja sosial dilihat sebagai satu profesion yang terbaik bagi mengendalikan isu gelandangan. Kompetensi yang ada pada pekerja sosial mampu memperkasakan golongan gelandangan ke arah kehidupan yang lebih baik dan sejahtera. Agensi yang menawarkan khidmat bantuan kepada golongan gelandangan perlu memastikan mereka mempunyai pekerja sosial yang terlatih dan berkemahiran tinggi dalam mengendalikan isu gelandangan, di samping dapat menyediakan pelan tindakan intervensi yang efektif dan akauntabiliti mengikut keperluan golongan gelandangan.
\end{abstract}

Kata kunci: akauntabiliti, gelandangan, intervensi, kompetensi, pekerja sosial, sokongan sosial 


\title{
Homeless knowledge of on the role and needs of social workers
}

\begin{abstract}
Homeless life is when an individual live without shelter and stable careers. In Malaysia, based on statistics reported by the Department of Social Welfare, the state which faced with homelessness issue are Kuala Lumpur, Selangor, Johor, Penang and Sarawak. The problems experienced by homeless individuals are poverty, severe mental and physical illness, alcohol and other substance abuse, unemployment and low wages. The qualitative study was conducted to identify the status of homeless awareness on the existence of agencies that provide intervention assistance and counseling services provided by social workers to the homeless especially in George Town, Penang. In-depth interviews have been conducted on 20 volunteers. The data obtained were analyzed using content analysis method. The findings show that homeless people are aware of the existence of private and government agencies that offer them assistance. However, it was found that the informant choosed not to obtain the services from these agencies. The reasons given by them is there is no need for them to meet the social workers, there is no certainty of getting help from the social workers, not knowing how to approach and not ready to share their problems. In this regard, this study suggests that social workers are the best person to handle homeless issues. The competence of the social workers could empower the homeless to a better and fulfilled life. Agencies offering aid services to homeless people should ensure that they have trained and highly skilled social workers in handling homeless issues as well as providing an effective and accountable intervention plan according to the needs of the homeless.
\end{abstract}

Keywords: accountability, homeless, intervention, competency, social worker, social support

\section{Pengenalan}

Kepincangan sosioekonomi seseorang individu mampu mengundang gangguan emosi hingga mendesak individu menjalani kehidupan bergelandangan akibat kesempitan hidup yang serba kekurangan. Kaedah penyelesaian masalah ini masih lagi diperdebatkan di pelbagai peringkat bagi mencari solusi yang terbaik dan sesuai dalam memenuhi keperluan golongan gelandangan.

Terdapat pelbagai takrifan gelandangan diberikan oleh pelbagai pihak dan sarjana berdasarkan kepada bidang kajian yang dilakukan. Menurut Dewan Bahasa dan Pustaka (2010), gelandangan adalah individu yang tidak mempunyai tempat tinggal dan pekerjaan yang tidak tetap. Menurut National Survey of Homeless Asisstance Provider and Clients (NSHAPC), gelandangan didefinisikan sebagai individu yang tinggal di satu tempat perlindungan kecemasan atau program perumahan peralihan (McKinney, 2008). Jabatan Kebajikan Masyarakat (JKM) pula mendefinisikan golongan gelandangan ini sebagai orang papa. JKM mendefinisikan orang papa ialah seseorang yang didapati mengemis di sesebuah kawasan tempat terbuka atau tempat awam hingga menyebabkan kegusaran dan kebimbangan kepada orang awam yang mengunjungi tempat tersebut ataupun hingga mengakibatkan kacau ganggu atau seseorang peleser yang dijumpai di sesuatu tempat awam sama ada atau tidak mengemis, yang tidak mempunyai sumber pendapatan pada zahirnya atau tempat tinggal atau yang tidak dapat menyatakan hal dirinya dengan baik. 
Manakala, The National Board of Health and Welfare (2001) mentakrifkan gelandangan adalah seseorang yang tidak memiliki tempat tinggal dan menjalani kehidupan yang bergantung kepada sumber alternatif sementara waktu. Seterusnya, Drani (2016) mentakrifkan golongan gelandangan sebagai individu yang tidak mempunyai rangkaian akses keperluan hidup yang stabil. Golongan ini mengalami masalah dan tekanan dalam kehidupan sehingga tidak mampu untuk menyediakan keperluan untuk diri sendiri dan keluarga. Tekanan daripada pengalaman yang dialami memaksa mereka hidup bergelandangan di persekitaran terbuka seperti tempat awam bagi meneruskan kelangsungan hidup.

Menurut McNeil et al. (2013) mengklasifikasikan golongan gelandangan sebagai golongan yang kehilangan tempat tinggal, golongan yang hilang kuasa sosial, golongan yang tidak mempunyai sumber kewangan yang baik dan golongan yang mengalami kemerosotan sosial. Kemusnahan dan kemerosotan kualiti hidup menjejaskan kemampuan golongan ini untuk memenuhi keperluan asas termasuk penjagaan kesihatan. Manakala menurut Daly (1996) gelandangan merupakan individu yang mempunyai tempat tinggal atau kediaman. Mereka juga merupakan individu yang tidak berkemahiran, gemar melakukan pekerjaan secara sementara dan tidak mempunyai tempat untuk bergantung. Kajian ini turut mengkategorikan bekas banduan dan pesakit mental yang tidak mempunyai tempat perlindungan sebagai gelandangan. Gelandangan tidak dapat dipisahkan dengan keadaan tidak ada tempat tinggal yang umumnya ramai pengkaji menyatakan sedemikian. Hal ini termasuk juga dengan ketiadaan wang ringgit, tidak mempunyai tempat mandi yang teratur, tidak mempunyai makanan dan perlindungan yang sempurna seperti individu yang menjadi kehidupan nomal (Moran \& Atherton, 2018).

Kajian yang dilakukan oleh Speak dan Tripple (2007) menunjukkan bahawa jumlah gelandangan yang terdapat di negara-negara membangun menjangkau 100 juta sehingga satu bilion. Di Malaysia, statistik jumlah gelandangan didapati masih lagi tidak jelas. Sebagai sebuah negara majmuk yang mempunyai rakyat yang berbilang kaum, statistik yang diperolehi menunjukkan bahawa golongan gelandangan terdiri daripada pelbagai kaum. Namun, bilangannya bergantung kepada jumlah majoriti kaum tertentu yang mendiami sesebuah tempat di dalam negeri yang terlibat.

Respon kepada permasalahan dan senario yang berlaku, satu kajian bagi mengetahui pengetahuan golongan gelandangan terhadap peranan dan keperluan pekerja sosial telah dilakukan. Sehubungan itu, artikel ini mendedahkan hasil dapatan kajian untuk membincangkan isu-isu yang berbangkit berkaitan perkhidmatan bantuan yang ditawarkan oleh agensi serta mengetengahkan peranan pekerja sosial dalam membantu golongan gelandangan.

\section{Kajian literatur}

\section{Gelandangan dan kehidupan bergelandangan}

Hidup dalam keadaan bergelandangan bukan satu situasi yang dimahukan oleh sesiapa. Namun, menjadi pilihan apabila masalah yang dihadapi tidak dapat diatasi dengan baik (Drani, 2016). Menurut Forchuk (2011) aktiviti bergelandangan adalah berpunca daripada tekanan dan ketidaksegaraman daripada sosioekonomi. Manakala, Gaetz et al. (2013) pula menyatakan bentuk komunikasi sosial yang tidak berlangsung dengan baik juga menyebabkan perkara ini berlaku. Menurut Johnson et al. (2015), individu yang menjalani kehidupan bergelandangan adalah disebabkan oleh masalah ekonomi, sosial hingga mengakibatkan kehilangan tempat 
tinggal. Seterusnya, kehilangan tempat tinggal bukan sahaja memberi kesan kepada fizikal dan psikososial individu bergelandangan, malah mereka turut dianggap sebagai orang yang hilang kuasa dalam masyarakat dan hak terhadap sumber sosial (Fitzpatrick et al., 2012). Menurut Bush-Geertsema (2010), individu yang bergelandangan akan mempunyai masalah dari segi hubungan sosial, dan rangkaian sosial. Selain itu, mempunyai halangan untuk menggunakan perkhidmatan sosial yang berkesan seperti mendapatkan pekerjaan, perkhidmatan bank dan lainlain perkara.

Kehidupan bergelandangan diburukkan lagi dengan pengalaman dan peristiwa hidup yang membawa kepada keadaan traumatik seperti kematian ahli keluarga, penderaan emosi, fizikal dan seksual. Malahan, mereka juga dijadikan sebagai mangsa untuk mendapatkan keuntungan oleh pihak yang tidak bertanggungjawab. Hepworth et al. (2006) menyatakan bahawa masalah gelandangan merupakan satu tekanan yang serius dan mampu menjejaskan fungsi kognitif, sistem sosial, tingkah laku dan fizikal individu yang bergelandangan. Menurut Walter (2016), kehidupan bergelandangan ini terbahagi kepada dua, iaitu (i) diakibatkan oleh tekanan daripada konteks sosial dan ekonomi yang dilihat berada di luar kawalan dan jangkaan individu tersebut dan (ii) disifatkan sebagai ciri individu atau pilihan peribadi untuk memilih menjalani kehidupan bergelandangan.

Di Malaysia kebanyakan gelandangan adalah kaum lelaki. Namun, berdasarkan hasil kajian yang dilakukan, terdapat peningkatan jumlah gelandangan yang terdiri daripada kaum wanita. Gelandangan di Malaysia juga didapati tidur di jalanan, laluan pejalan kaki, khususnya bagi kaum lelaki. Manakala, kaum wanita memilih untuk menyewa bilik bagi menjaga keselamatan mereka (Nor et al., 2016). Menurut Farrah et al. (2018), di Malaysia, individu memilih untuk menjalani kehidupan bergelandangan disebabkan oleh sikap malas berusaha, tidak mempunyai kekuatan menghadapi kesulitan hidup, mempunyai konflik keluarga dan diisytihar muflis. Keadaan ini memberi tekanan terhadap struktur kehidupan dan kesejahteraan hidup golongan gelandangan itu sendiri.

Lukman dan Asyikin (2014), mendapati individu yang bergelandangan bukan golongan masyarakat yang paling rendah/bawah (lumpenproletariat), tetapi mereka adalah individu yang berhadapan dengan tekanan dan kesempitan hidup yang diakibatkan oleh kos perbelanjaan sara hidup yang tinggi, masalah perumahan, ketiadaan tempat bergantung menyebabkan mereka menjalani kehidupan sebagai gelandangan. Menjalani kehidupan bergelandangan menyebabkan individu tersebut terpaksa menagih ihsan dan bantuan orang awam bagi mendapatkan bantuan makanan, pakaian, kewangan dan sebagainya bagi meneruskan kelangsungan hidup (Drani, 2016).

Kewujudan gelandangan di Malaysia antaranya didorong oleh faktor ketiadaan waris atau status perkahwinan mereka. Menurut Mohd et al. (2016), kebanyakan gelandangan yang di selamatkan oleh pihak Jabatan Kebajikan Masyarakat dan di tempatkan di Kem Desa Bina Diri (DBD) Jerantut Pahang, didapati masih bujang dan tidak pernah berkahwin. Malahan, dalam kalangan mereka berstatus duda atau janda akibat berlakunya penceraian. Di samping itu, golongan ini juga dilihat tidak mendapat sokongan sosial daripada ahli keluarga ekoran ketiadaan waris yang dapat menjaga apabila meningkat usia.

\section{Peranan pekerja sosial kepada golongan gelandangan}

Profesion kerja sosial bertindak dan berperanan untuk meningkatkan kualiti dan kefungsian hidup individu, kumpulan, komuniti dan masyarakat. Penglibatan profesion kerja sosial sebagai 
agen pengubah dilihat sangat penting dan satu keperluan segera bagi mengetengahkan kaedah intevensi bersesuaian dalam menangani masalah ini secara holistik dan berakauntabiliti. Memahami secara mendalam tentang golongan gelandangan adalah sesuatu cabaran yang unik dan memerlukan usaha serta komitmen yang tinggi. Penelitian tentang gelandangan dikatakan akan memberi satu tekanan terhadap bidang kerja sosial. Hal ini kerana individu yang bergelandangan merupakan golongan yang kurang memberi respon apabila didekati (Aviram \& Katan, 1991).

Respons kepada permasalahan ini, pekerja sosial dilihat sebagai satu profesion yang sangat diperlukan dalam membantu memperkasakan golongan gelandangan. Drani (2016) menegaskan tanggungjawab pekerja sosial supaya memainkan peranan secara aktif dalam mengurangkan kesan psikososial yang mampu mencabar kesejahteraan hidup golongan gelandangan. Profesion ini harus bertindak tanpa perlu menunggu sehingga sesuatu perkara atau isu menjadi serius. Perkara ini jelas seperti yang ditekankan oleh International Federation of Social Workers (IFSW) dan International Association of School of Social Work (IASSW) (2004) bahawa profesion kerja sosial merupakan agen pengubah dalam sistem sosial yang memfokuskan kepada proses penyelesaian masalah.

Profesion kerja sosial merupakan profesion yang berorientasikan matlamat. Peranan pekerja sosial yang optimum adalah untuk menyumbang kepada peningkatan kehidupan yang lebih baik dan sejahtera dengan membantu menghentikan sebarang bentuk kemerosotan yang dialami oleh individu serta mencegah berlakunya pengulangan keadaan negatif. Intervensi yang diaplikasikan oleh seorang pekerja sosial yang berorenstasikan matlamat adalah melalui perancangan yang berstruktur mengikut keperluan individu dan bukan hanya membiarkan masalah tersebut kian berlarutan (Hutchinson, 2014).

Pekerja sosial mempunyai keupayaan dalam memperkasa dan memperjuangkan kebebasan untuk meningkatkan kesejahteraan hidup masyarakat. Prinsip hak asasi manusia dan keadilan sosial merupakan asas kepada profesion kerja sosial. Keutamaan profesion ini adalah menjaga hak kesamaan dan keseimbangan sosial dalam masyarakat. Setiap perkhidmatan yang disediakan dilakukan dengan penuh toleransi dan demokrasi supaya golongan yang dibantu mendapat perkhidmatan yang adil dan saksama. IFSW dan IASSW (2004) menyatakan bahawa profesion kerja sosial mampu melakukan pelbagai tugas dan peranan bagi mengelakkan sebarang bentuk diskriminasi. Ia juga bagi menggalakkan penyertaan sosial oleh pelbagai pihak.

Englebrecht (1999) menyatakan bahawa pekerja sosial mempunyai pengetahuan, nilai dan kemahiran serta kualiti personaliti yang cekap dalam mengendalikan isu-isu sosial. Sheafor et al. (1994) menyatakan bahawa pekerja sosial sentiasa percaya bahawa setiap orang mampu berubah, dan berkembang. Hal ini kerana profesion kerja sosial berpegang kepada nilai dalam setiap perkhidmatan yang diberikan. Antaranya nilai yang dipegang oleh pekerja sosial adalah:

\section{a. Menjaga maruah klien}

Pekerja sosial sentiasa menghormati keunikan yang dibawa oleh klien. Klien akan lebih yakin dengan intervensi yang diberikan oleh pekerja sosial apabila pendekatan yang digunakan membuatkan klien rasa dihormati. 


\section{b. Penerimaan}

Pekerja sosial mampu memberi perkhidmatan dengan baik tanpa mengambilkira latar belakang klien. Dalam profesion kerja sosial, individu perlu dilihat dalam konteks keadaannya tanpa sebarang stigma kerana karakteristik yang dibawa adalah berdasarkan kepada persekitaran dan masalah yang sedang dilalui oleh mereka.

\section{c. Tidak menghukum}

Pekerja sosial yang memberi khidmat bantuan kepada klien tidak akan meletakkan nilai menghukum. Hal ini kerana pekerja sosial yang sentiasa menjalankan perkhidmatan dengan profesional akan melihat kepada objektif yang disasarkan.

\section{d. Keindividuan}

Pekerja sosial mempunyai pemahaman yang amat luas berkaitan nilai keindividuan. Setiap manusia mempunyai keperluan dan situasi yang unik serta berbeza. Hal ini kerana pengalaman juga berbeza, justeru nilai keindividuan amat diutamakan dalam proses pertolongan.

\section{e. Penentuan kendiri}

Klien mempunyai hak dan kebebasan untuk membuat keputusan sendiri dalam kehidupan mereka tanpa dipengaruhi oleh kepentingan pihak luar. Malah, mereka harus diberi peluang untuk memikul tanggungjawab melakukan sesuatu untuk memperbaiki keadaan mereka.

\section{f. Kerahsiaan}

Pekerja sosial amat memegang prinsip kerahsiaan. Klien sukar berkongsi maklumat dengan orang luar. Oleh itu, setiap maklumat yang diberikan disimpan dengan penuh amanah dan dikendalikan dengan baik dan bijak.

\section{g. Penglibatan emosi}

Pekerja sosial yang profesional tidak akan melibatkan sebarang bentuk hubungan melibatkan emosi semasa menjalankan tugas dan perkhidmatan kepada klien. Pekerja sosial bagaimanapun tidak boleh menjadi subjek yang terlibat secara tidak terkawal dalam keadaan klien. Perkara ini akan mengurangkan hala tuju yang disasarkan yang akan merugikan klien dan situasi.

Kecekapan pekerja sosial dalam menegakkan keadilan sosial terhadap semua bentuk percanggahan dan ketidaksamarataan di semua peringkat amat diperlukan. Perkara ini bagi mengelakkan berlakunya keciciran terhadap golongan minoriti dalam mengecapi arus global. Hak asasi manusia adalah asas kepada semua individu dan haruslah diagihkan dengan baik kerana setiap orang berjuang untuk setiap keperluan asas mereka (IFSW, 2004). 


\section{Metod dan kawasan kajian}

Kajian menggunakan pendekatan fenomenologi dengan melakukan temu bual secara mendalam. Menurut Cresswell (2007), kajian berbentuk fenomenologi dapat menyediakan pengetahuan dan pengalaman mendalam tentang isu yang dikaji. Menurut Donalek (2004), kajian yang menggunakan pendekatan fenomenologi digunakan untuk mengkaji pengalaman hidup seseorang individu melalui penceritaan yang telus berdasarkan kepada pengalaman yang dilalui oleh informan. Manakala menurut Allan dan Robert (1999), kajian yang berbentuk kualitatif lebih sensitif terhadap persekitaran kajian dan bersifat holistik atau menyeluruh terhadap sesuatu isu yang dikaji.

Kajian yang dijalankan menemu bual 20 orang informan dengan menggunakan teknik pensampelan bertujuan berasaskan reka bentuk fenomenologi. Cresswell (2007) menyatakan bahawa reka bentuk penyelidikan fenomenologi kebanyakannya berurusan dengan saiz sampel yang kecil kerana ciri-ciri kajian adalah mendalam dari segi pengumpulan data. Lima (5) hingga 25 orang informan mencukupi untuk membangunkan kefahaman yang jelas tentang subjek yang dikaji berdasarkan kepada isu yang diketengahkan. Informan kajian ini terdiri daripada pelbagai kaum seperti Melayu, Cina dan India. Kajian ini dilakukan di sekitar kawasan Georgetown, Pulau Pinang dengan menumpukan lokasi utama yang menjadi tempat tumpuan golongan gelandangan. Antara lokasi yang tersebut adalah sekitar Masjid Kapitan Keling, jeti, KOMTAR, tempat perhentian bas dan Lebuh Chulia.

Kaedah pengumpulan data bagi penyelidikan ini dilakukan melalui kaedah temu bual secara mendalam dengan menggunakan soalan separa struktur dan soalan terbuka. Menurut Shank (2002), soalan temu bual terbuka digunakan dalam kajian kualitatif untuk membolehkan informan berkongsi pengalaman mereka. Temu bual mendalam telah dilakukan dengan menggunakan bahasa Melayu dan bahasa "pasar" bagi memudahkan informan memahami soalan yang diajukan.

Neuman (2003) menegaskan bahawa tanggungjawab penyelidik adalah untuk melindungi kerahsiaan informan. Penyelidik harus memastikan bahawa maklumat yang diterima tidak terdedah kepada orang lain. Burns dan Grove (2001) menuntut pengkaji supaya mengekalkan kerahsiaan ketika menjalankan penyelidikan kualitatif. Bagi menjaga kerahsiaan maklumat dan peribadi informan daripada dikenali, kesemua informan yang terlibat diwakili dengan kod iaitu R1 sehingga R20.

\section{Hasil kajian}

Kajian telah menemu bual secara mendalam dua puluh (20) orang respoden yang terlibat secara sukarela. Informan yang terlibat dalam kajian terdiri daripada dua belas (12) informan berbangsa Melayu, empat (4) orang informan berbangsa Cina dan empat (4) orang informan berbangsa India. Dari segi jantina, informan kajian terdiri daripada tujuh belas (17) lelaki dan tiga orang (3) wanita. Informan telah diajukan soalan berkaitan sama ada mereka mengetahui tentang kewujudan agensi yang memberi khidmat bantuan dan sokongan sosial kepada mereka. Kebanyakan mereka menyatakan mereka mengetahui tentang kewujudan agensi yang menyediakan khidmat bantuan kepada golongan yang memerlukan. Meskipun mereka mengetahui tentang perkhidmatan yang disediakan, ada dalam kalangan informan yang ditemu bual menolak untuk dibantu atas alasan tersendiri. 


\section{Pengetahuan gelandangan tentang agensi khidmat kebajikan dan sokongan sosial}

Hasil kajian menunjukkan bahawa golongan gelandangan mengetahui tentang kewujudan khidmat sokong bantu yang ditawarkan di agensi kerajaan dan swasta. Golongan ini melihat institusi kebajikan yang menawarkan perkhidmatan kebajikan hanya menumpukan kepada bantuan kewangan. Kesukaran berurusan dengan pihak agensi membuatkan mereka mempunyai perspektif dan alasan tersendiri dalam mendapatkan khidmat yang ditawarkan. Malah individu yang terlibat didapati mengetahui tentang kewujudan pekerja sosial dan kaunselor yang memberi perkhidmatan khidmat nasihat dan intervensi. Namun mereka tidak pernah mendapatkan perkhidmatan yang disediakan.

Daripada temu bual yang dijalankan, kesemua informan yang terlibat iaitu seramai 20 menyatakan bahawa mereka sedia maklum terdapat agensi yang menyediakan perkhidmatan bantuan dan sokongan sosial. Kesemua mereka telah menyenaraikan agensi seperti Jabatan Kebajikan Masyarakat, Light House (gereja) dan KAWAN sebagai agensi yang menyediakan perkhidmatan bantuan dan sokongan sosial kepada golongan gelandangan. Berikut merupakan sebahagian daripada pernyataan yang dikongsikan oleh informan dalam kajian ini. Berikut merupakan sebahagian hasil petikan temu bual bersama informan yang terlibat dalam kajian ini.

“...Tapi saya tidak minta. Susah mahu dapat” (Informan 1).

“...Tahu, JKM (merujuk kepada Jabatan Kebajikan Masyarakat). Pihak Church pun ada.. selalu mereka datang hantar dan beri makanan" (Informan 4).

“...Saya tahu.. JKM saya tahu” (Informan 7).

“...Di Komtar ada Jabatan Kebajikan Masyarakat, kemudian pihak swasta juga ada. Nama agensi saya tidak tahu. Ada kawan saya pergi makan di sana mereka sediakan" (Informan 8).

"...Saya tahu.. banyak di sini.. ada JKM, ada Light House...di hadapan sana KAWAN.. macam-macam.. saya tahu..”(Informan 11).

“...Sekiranya kerajaaan, JKM yang saya tahu. Kalau swasta seperti Light House.. KAWAN, ada dua tiga lagi tapi saya tidak tahu nama agensi tersebut" (Informan 13).

“...Ada agensi seperti Light House, JKM..” (Informan 17).

Menurut Osborne (2002), golongan gelandangan bukan golongan yang suka meminta-minta. Hal ini dibuktikan apabila hasil kajian menunjukkan bahawa golongan bergelandangan menolak untuk mendapatkan perkhidmatan pekerja sosial mahupun kaunselor. Informan dalam kajian ini menyatakan bahawa mereka tidak memerlukan sebarang perkhidmatan khidmat nasihat kerana mereka berpendapat mereka tidak mempunyai masalah untuk dikongsikan. Malah, tiada keperluan untuk berjumpa dengan pekerja sosial dan kaunselor bagi mendapatkan nasihat dan bantuan.

Sehubungan itu, golongan gelandangan dilihat kurang memahami peranan dan tanggungjawab pekerja sosial dan kaunselor di agensi dalam membantu memperkasakan mereka 
untuk meningkatkan keupayaan dalam memartabatkan kehidupan agar dapat berfungsi dengan baik. Perkara ini sekali gus menjurus kepada kewujudan pelbagai persepsi, pendapat, salah tanggapan dan sikap yang pada asasnya disebabkan oleh kurang pengetahuan tentang kegunaan khidmat kaunseling dan sokong bantu. Oleh itu, satu pendekatan baharu perlu dilakukan dengan mengetengahkan fungsi, peranan dan kebolehan pekerja sosial dalam membantu meningkatkan kualiti hidup golongan gelandangan. Selain itu, penyampaian maklumat tentang peranan dan keperluan mendapatkan khidmat kaunseling perlu diperluaskan supaya mereka lebih faham dan dapat menimbulkan minat untuk berkongsi maklumat dalam menyelesaikan masalah. Mendapatkan khidmat nasihat dari golongan yang profesional dalam mengendalikan masalah adalah lebih baik daripada orang perseorangan yang kurang mahir untuk membantu menyelesaikan masalah mereka.

Keperluan kepada pekerja sosial untuk menyediakan perkhidmatan dan respon kepada masalah ini adalah amat tinggi. Ini kerana, pekerja sosial menerapkan etika profesional dalam perkhidmatan yang ditawarkan bagi memastikan pegawai yang memberi khidmat nasihat dan bantuan secara telus dan bijak dalam membuat keputusan. Etika merupakan satu perkara penting dalam pelaksanaan tugas kerana matlamat utama digubal adalah untuk membimbing pegawai ke arah tahap profesional yang lebih tinggi (Francis, 2009). Melalui penggunaan etika, secara tidak langsung akan memandu pegawai berkhidmat dengan lebih baik. Setiap individu yang datang mendapatkan khidmat akan merasakan tindakan mereka betul, berasa selamat, serta mempunyai saluran yang tepat untuk berkongsi masalah.

\section{Penolakan gelandangan terhadap perkhidmatan sokong bantu}

Mengetahui dan menyelami secara mendalam tentang golongan gelandangan adalah sesuatu cabaran yang unik dan memerlukan usaha dan komitmen yang tinggi. Kerja sosial adalah satu profesion yang mempunyai kecekapan dalam memberi respon untuk menangani isu-isu yang melibatkan gangguan terhadap kefungsian sosial manusia (International Federation Social Wokers, 2000). Kepakaran dan kemahiran yang ada pada pekerja sosial mampu memperkasakan golongan ini supaya menikmati kesejahteraan hidup yang sempurna.

Berdasarkan temu bual yang dijalankan didapati majoriti iaitu seramai 15 informan yang ditemu bual tidak pernah meminta bantuan dengan pihak agensi bagi tujuan meringankan beban yang ditanggung. Hal ini berlaku kerana ada di antara mereka yang tidak tahu cara bagaimana untuk berhubung dengan pihak agensi. Selain itu, tindakan mereka tidak memohon bantuan juga adalah disebabkan oleh pandangan mereka yang menyatakan bahawa terdapat banyak birokrasi dalam mendapatkan khidmat bantuan daripada agensi. Namun, terdapat segelintir daripada mereka yang pernah memohon bantuan, tetapi masih belum mendapat jawapan daripada pihak yang berwajib.

Penyelidik juga mendapati bahawa golongan ini didapati tidak pernah mendapatkan sebarang bentuk khidmat nasihat daripada pekerja sosial atau kaunselor yang berada di setiap agensi. Mereka menyatakan tidak memerlukan khidmat nasihat, di samping tidak mempunyai sebarang maklumat untuk dikongsikan dengan pekerja sosial mahupun kaunselor. Selain menyatakan tidak berminat untuk mendapatkan khidmat nasihat, golongan ini juga berpendapat bahawa pekerja sosial dan kaunselor tidak dapat membantu mereka dalam menyelesaikan masalah yang dihadapi. Berikut merupakan sebahagian hasil petikan temu bual bersama informan yang terlibat dalam kajian ini. 
“...Tidak ada. Saya berpendapat saya tidak perlukan... belum tentu mereka boleh membantu. Mohon bantuan susah untuk dapat apatah lagi nasihat...mereka tidak mahu membantu. Saya juga malas untuk ke sana. Sekiranya ada bantuan, saya ambil, sekiranya tidak ada saya tidak kisah. Semua sama sahaja. Anjing kurap tersepit bukan semua orang mahu tolong lepaskan. Orang geli. Saya diibaratkan begitu..." (Informan 7).

“...Tidak ada. Saya rasa tidak ada apa tujuan untuk berumpa. Tidak tahu mahu minta apa. Kalau orang tidak mahu layan susah juga. Setakat ini memang tidak ada ..” (Informan 13)

"...Malu hendak pergi kepada mereka. Tambahan saya pun tidak tahu cara hendak pergi jumpa mereka. Terdapat banyak sangat proses. Saya tidak pandai. Mahu dikatakan susah sangat tidak. Saya ada kerja. Perihal makan tidak susah hati, sekiranya terdesak nanti saya pergi.." (Informan 16).

"Saya tidak mahu lagi. Saya perlukan masa, apabila saya telah bersedia. Sekarang saya masih serabut lagi."

(Informan 18)

"Tidak ada. Mahu minta nasihat apa, saya tiada masalah. Sudah bertahun macam ni... saya tidak serabut ... baik sahaja... mahu apa lagi” (Informan 19).

"Tiada nasihat yang diperlukan. Semua baik sahaja. Saya ada kerja, ada makanan, ada tempat tidur. Cukup. Perkara remeh temeh saya tidak ambil tahu. Cukup dengan jaga diri sendiri" (Informan 20).

\section{Perbincangan}

Kerja sosial merupakan profesion yang profesional. Keutamaan profesion adalah bertujuan menyediakan pelan rancangan dan tindakan intervensi dalam membantu klien untuk memenuhi keperluan dan meningkatkan kesejahteraan mereka. Bagi memberikan respon kepada klien, pekerja sosial harus mempunyai pelbagai kemahiran yang bersifat holistik (Trevithick, 2008). Berdasarkan kajian yang dilakukan, informan menyatakan bahawa mereka mengetahui tentang kewujudan pekerja sosial yang menyediakan perkhidmatan intervensi dan sokong bantu di agensi. Antara agensi kerajaan dan swasta yang dinyatakan oleh informan adalah seperti JKM, Light House, Church dan KAWAN. Agensi yang dinyatakan oleh informan merupakan agensi yang bergiat aktif dalam memberi khidmat kebajikan dan perkhidmatan sokongan kepada golongan yang memerlukan.

Berdasarkan kajian yang dilakukan, majoriti informan menyatakan bahawa mereka menolak untuk mendapatkan khidmat daripada pekerja sosial disebabkan oleh beberapa faktor. Antaranya adalah menjurus kepada tiada keperluan untuk berjumpa pekerja sosial, tiada kepastian pekerja sosial untuk membantu, tidak mengetahui cara dan kaedah untuk berjumpa dengan pekerja sosial serta belum bersedia untuk berkongsi masalah. Hal ini menunjukkan bahawa golongan ini 
kurang memahami peranan yang dimainkan oleh pekerja sosial dalam membantu mengurangkan masalah mereka.

Hasil temu bual bersama informan, sebagai individu yang bergelandangan, mereka tidak mempunyai sebarang keperluan untuk berjumpa dengan pekerja sosial. Duckworth et al. (2005) menyatakan individu yang bergelandangan telah mengalami situasi yang buruk dan kesukaran yang paling teruk untuk membina kembali jati diri dan kekuatan dengan mencari kegembiraan bagi menghilangkan kesedihan mereka. Golongan ini enggan memahami perkhidmatan yang disediakan oleh mana-mana badan yang bertanggungjawab untuk membantu mereka kerana telah melalui satu situasi yang sukar dalam kehidupan mereka. Oleh itu, mereka merasakan bahawa tiada keperluan untuk mendapatkan khidmat daripada pihak tertentu.

Selain itu, hasil kajian yang diperolehi mendapati informan turut menyatakan bahawa tiada kepastian pekerja sosial dapat membantu menyelesaikan masalah mereka. Kebanyakan informan yang ditemu bual menyatakan mereka telah kehilangan sokongan sosial daripada ahli keluarga dan saudara mara. Pekerja sosial adalah orang luar yang tidak mempunyai sebarang kaitan dan pertalian dengan mereka, namun cuba menghulurkan bantuan. Menurut Karabanow (2006), individu yang bergelandangan lebih selesa berkomunikasi dengan rakan sebaya dalam situasi yang sama bagi mendapatkan sokongan emosi, sosial dan fizikal. Mereka hanya berbincang dalam kalangan mereka tanpa merujuk atau mendapatkan khidmat daripada pihak agensi. Taylor et al. (2004) menyatakan hubungan "rakan jalanan" lebih bermakna dan lebih memahami tentang situasi yang dialami. Mereka membentuk sebagai ahli keluarga dalam kalangan mereka dan mencerminkan peranan sebagai penasihat. Mereka juga dikatakan tidak mempunyai kepercayaan terhadap orang lain. Perkara ini menjadi penyebab kepada persoalan yang timbul apabila keakraban dan kepercayaan mereka hanya tertumpu kepada "rakan jalanan" yang dilihat lebih memahami.

Selain itu, informan turut menyatakan bahawa mereka tidak tahu cara atau kaedah berurusan dengan pihak agensi memandangkan terdapat banyak proses yang perlu dilakukan. Oleh yang demikian, mereka bertindak untuk tidak mendapatkan perkhidmatan yang disediakan. Kajian ini selari dengan kajian yang dijalankan oleh Applewhite (1997) yang menyatakan bahawa golongan gelandangan kebiasaannya mempunyai masalah dengan perkhidmatan yang disediakan oleh agensi. Hasil kajian tersebut menunjukkan bahawa kebanyakan golongan gelandangan sering mengalami kesukaran mengakses sistem dan perkhidmatan akibat daripada maklumat yang kurang jelas, maklumat yang terhad, perkhidmatan yang disediakan tidak memenuhi keperluan mereka dan proses yang sedia ada tidak dapat dilaksanakan dengan berkesan serta sistem yang direka untuk memenuhi kepentingan mempunyai birokrasi.

Seterusnya, informan juga menyatakan bahawa mereka belum bersedia untuk berkongsi masalah yang dihadapi. Thompson et al. (2010) menyatakan bahawa golongan ini merupakan individu yang terpisah daripada sokongan institusi sosial dan memerlukan ruang dan peluang untuk membolehkan mereka berkongsi. Walau bagaimanapun, golongan ini hanya bersedia untuk berkongsi apabila mereka sedar tentang keupayaan mereka untuk melakukan perubahan positif ke arah masa depan yang lebih produktif. 


\section{Kesimpulan}

Kajian ini mencadangkan agar golongan minoriti ini didedahkan dengan maklumat yang betul dan tepat bagi membolehkan golongan gelandangan memahami keperluan dan peranan pekerja sosial dalam membantu memberi intervensi yang efektif kepada mereka. Pihak agensi kerajaan dan swasta yang menawarkan khidmat kebajikan dan mempunyai pekerja sosial mestilah berupaya untuk menyediakan perkhidmatan yang baik dan mesra golongan gelandangan bagi memudahkan sebarang urusan yang ingin dilakukan.

Sehingga kini, masih tidak ada dasar yang menekankan kepada peranan pekerja sosial untuk membantu golongan gelandangan. Namun, hakikatnya keperluan terhadap profesion ini adalah sangat tinggi ekoran praktis dan pendekatan yang digunakan oleh pekerja sosial adalah berbeza dan ia bersifat menyeluruh dan berakauntabiliti. Pekerja sosial juga harus melakukan tinjauan ke lapangan dan menyampaikan maklumat supaya golongan ini merasakan masih ada harapan untuk kembali menjalani kehidupan normal seperti individu lain.

Integrasi secara bersepadu perlu dilaksanakan dalam kalangan pekerja sosial di agensi kerajaan, mahupun swasta untuk memaklumkan kepada pihak kerajaan agar dapat mewujudkan polisi sosial yang memfokuskan kepada peranan dan keperluan pekerja sosial yang kompeten di Malaysia. Melalui dasar tersebut, profesion ini akan dapat dimanfaatkan sebaik mungkin dalam membantu mengupayakan semua golongan gelandangan.

\section{Penghargaan}

Kajian ini telah dibiayai sepenuhnya oleh Geran Penyelidikan Jangka Pendek Universiti Sains Malaysia 2017-2019- 1001/PSOSIAL/AUPSE0014 yang diketuai oleh Dr. Syazwani Drani.

\section{Rujukan}

Allan, B., \& Robert, B. G. (1999). Qualitative Research. (Vol. 4), London, Sage.

Applewhite, S.L. (1997). Homeless veterans: Perspectives on social services use. Retrieved from https://www.researchgate.net.

Aviram, U., \& Katan (1991). Professional preference of social worker: Prestige scales of populations, services, and methods in social work. International Social Work, 34(1), 37-55.

Burns, N., \& Grove, S.K. (2001). The practice of nursing research: Conduct, critique, \& utilization. ( $4^{\text {th }}$ ed.). Philadelphia, Saunders.

Bush-Geertsema, V., 2010. The Finnish National Programme to reduce longterm homelessness. synthesis report, Brussels: European Commission Employment, Social Affairs and Inclusion. Retrieved from http://ec.europa.eu/social/main.jsp?

Cresswell, J.W. (2007). Qualitative inquiry and research design: Choosing among five approaches. United Stated of America, Sage Publication.

Daly, G. (1996). Homeless: Policies, strategies, and lives on the street. London, Routledge.

Dewan Bahasa dan Pustaka. (2010). Kamus Dewan. (4 ${ }^{\text {th }}$ ed.). Kuala Lumpur, Dewan Bahasa dan Pustaka.

Drani, S. (2016). Dinamik kehidupan golongan gelandangan di Pulau Pinang. Penyelidikan, Universiti Sains Malaysia. 
Donalek, J.G. (2004). Demystifying nursing research: Phenomenology as a qualitative research method. Urologic Nursing, 516-517.

Duckworth, A.L., Steen, T.A., \& Seligman, M.E.P. (2005). Positive psychology in clinical practice. Annual Review of Clinical Psychology, 1, 629-651.

Engelbrecht, K.L. (1999). Social work introduction. Lonzo, Wellington.

Farrah, W.M., Faudziah, Y., Mohd, T.D., Fazurah, M., Mohammad, Y.O.M., Amirul, N.A., Mohd, H.M., \& Izzat, H.O. (2018). 'Trend' dan implikasi peningkatan gelandangan. Retrieved from https://www.researchgate.net.

Fitzpatrick, C., Pawson, S., Bramley, H., \& S. Wilcox. (2012). The homelessness monitor: Scotland 2012. London, Crisis.

Forchuk, C., Scholfield, R., Joplin, L., Csiernik, R., Gorlick, C., \& Turner, K. (2011). Housing, income support, and mental health: Points of disconnection. London, Crisis.

Francis, R. D. (2009). Ethics for psychologists. ( $2^{\text {nd }}$ Ed.). United Kingdom, BPS Blackwell. Gaetz, S.A., Donaldson, J., Richter, T., \& Gulliver, T. (2013). The state of homelessness in Canada 2013. Toronto, Canadian Homelessness Research Network Press. Retrived from http://www.homelesshub.ca.

Hepworth, D.H., Rooney, R.H., Rooney, G.D., Strom-Gottfried, K., \& Larsen, J.H. (2006). Direct social work practice: Theory and skills. ( ${ }^{\text {th }}$ Ed.). CA, Brooks Cole.

Hutchinson, S., Page, A., \& Sample, E. (2014) Rebuilding Shattered Lives: The Final Report. London. Retrieved from http://rebuildingshatteredlives.org.

International Association of School of Social Work. (2004). Definition of social work. Retrived from http://www.ifsw.org.

International Federation of Social Workers, (2000). Definition of social work. Retrieved from www.ifsw.org/pulication/4.6e.pub.html.

Johnson, G., Scutella, R., Tseng, Y.P., \& Wood, G. (2015). Entries and exits from homelessness: A dynamic analysis of the relationship between structural conditions and individual characteristics (AHURI Final Report No. 248). Melbourne, AHURI.

Karabanow, J. (2006). Becoming a street kid: Exploring the stages of street life. Journal of Human Behavior in the Social Environment, 13(2), 49-72.

Lukman, Z.M., \& Asyikin, S.S. (2014). Gelandangan atau lumpenproletariat? Memahami masalah kemiskinan bandar dan fenomena tidur di kaki lima bangunan. Proceeding of the $50^{\text {th }}$ Anniversary Celebration International Conference. 15 Mei.

McKinney, V. (2008). National Alliance to End Homelessness: Legislative updates. Retrieved from http://www.endhomelessness.org.

McNeil, R., Guirguis-Younger, M., Dilley, L.B., Turnbull, J., \& Hwang, S.W. (2013). Learning to account for the social determinants of health affecting homeless persons. Medical Education, 47, 485-494.

Mohd, S.M., Khaidzir, I., Nasrudin, S., \& Nik, H.O. (2016). Hubungan di antara kesihatan mental dengan minat kerjaya dalam kalangan gelandangan di Kem Desa Bina Diri, Malaysia. Akademika, 86(1), 11-19.

Moran, F., \& Atherton, F. (2018). The philosophy of homeless: Barely being (2019). New York, Routledge.

Neuman, W.L. (2003). Social research methods: Qualitative and quantitative approaches. $\left(5^{\text {th }}\right.$ ed.). Boston, Allyn \& Bacon.

Nor, A.M.A., Zaliha, H., \& Yarina, A. (2016). Homeless women in Malaysia: Their choice or victims of situations. Journal of Education and Social Sciences, 5(3), 8-15. 
Osborne, R.E. (2002). "I may be homeless, but I'm not helpless": The costs and benefits of identifying with homelessness. Self and Identity, 1(1), 43-52.

Shank, G. (2002). Qualitative research: A personal skills approach. Upper Saddle River, NJ, Merrill, Prentice Hall.

Sheafor, B.W., Horejsi, C.R., \& Horejsi, G.A. (1994). Techniques and guidelines for social work practice. ( $3^{\text {rd }}$ ed.). Boston, Allyn and Bacon.

Speak, S., \& Tipple, A.G. (2007). Housing and homelessness in developing nations. In Levinson, \& Ross (Eds.), Homelessness handbook. Berkshire, Open University Press.

The National Board of Health and Welfare (2001). Whats is the official definition of homeless? Retrieved from https://www.nhchc.org/faq/official-definition-homelessness/

Taylor, D.M., Lydon, J.E., Bougie, É., \& Johannesen, K. (2004). "Street kids": Towards an understanding of their motivational context. Canadian Journal of Behavioural Science/Revue Canadienne des Sciences du Comportement, 36(1), 1-16.

Thompson, S.J., Jun, J., Bender, K., Ferguson, K.M., \& Pollio, D.E. (2010). Estrangement factors associated with addiction to alcohol and drugs among homeless youth in three U.S. cities. Evaluation and Program Planning, 33, 418-427.

Trevithick, P. (2008). Revisiting the knowledge base of social work: A framework for practice. British Journal of Social Work, 38(6), 1212-1237.

Walter, Z.C. (2016). Transitions through homelessness: The impact of pychosocial factors on wellbeing and outcomes in a homeless sampel (Phd dissertation). Retrieved from University of Queensland Australia. 